\title{
PERANCANGAN SISTEM APLIKASI INVENTORY TOKO OUTDOOR BERBASIS JAVA PADA CV LATAR OUTDOOR
}

\author{
Deswil Violla Tanjung ${ }^{1}$, Fiqih Ismawan, M.Kom ${ }^{2}$, Umar Wirantasa, M.Pd ${ }^{3}$ \\ ${ }^{1,2,3)}$ Program Studi Informatika, Fakultas Teknik dan Ilmu Komputer, Universitas Indraprasta PGRI \\ Jalan Raya Tengah No 80, Kelurahan Gedong, Pasar Rebo, Jakarta Timur \\ email: deswil19@gmail.com¹, VQ.unindra@gmail.com², wirantasaumar@gmail.com³
}

\begin{abstract}
Abstrak
Tujuan Penelitian adalah untuk mengetahui sistem yang berjalan dalam pencatatan pengadaan barang dan penjualan di inventory Toko Latar Outdoor menggunakan bahasa pemrograman Java Netbeans. Pengembangan sistem inventory menggunakan model waterfall. Sistem ini dirancang menggunakan Entity Relationship Diagram (ERD) sebagai perancangan database dan Data Flow Diagram (DFD) sebagai perancangan alur data. Sistem ini dibangun dengan bahasa pemrograman Java Netbeans dan database MySQL. Hasil dari Sistem inventory pada Toko Outdoor yaitu dapat mengetahui proses pemesanan dan pembelian barang, pencatatan data barang, pencatatan barang masuk, pencatatan barang keluar, pencatatan barang afkir, pencatatan pengembalian barang afkir dan pencatatan data supplier. Sehingga sistem ini dapat membantu pengurusan dalam mengolah data administrasi pada Toko Latar Outdoor.
\end{abstract}

Kata Kunci: Perancangan Sistem Aplikasi Inventory, Java.

\begin{abstract}
The purpose of this research is to find out the system that runs in recording the procurement of goods and sales in the inventory of the Latar Outdoor Store using the Java Netbeans programming language. Inventory system development using the waterfall model. This system is designed using Entity Relationship Diagram (ERD) as database design and Data Flow Diagram (DFD) as data flow design. This system is built with Java Netbeans programming language and MYSQL database. The results of the inventory system at the Latar Outdoor Store are able to know the process of ordering and purchasing goods, recording goods data, recording incoming goods, recording goods out, recording rejected goods, recording returns of rejected goods and recording supplier data. So that this system can assist management in processing administrative data at the Latar Outdoor Store.
\end{abstract}

Keyword: Inventory Application System Design, Java.

\section{PENDAHULUAN}

Inventory Toko Latar Outdoor sebagai instansi yang menyediakan penjualan dan pengadaan barang dan jasa. Instansi tersebut memerlukan sistem informasi berbasis komputer untuk mengelola data dan menghasilkan laporan - laporan yang akurat. Hal tersebut diperlukan karena inventory Toko Latar Outdoor menggunakan metode manual sehingga masih memiliki berbagai kekurangan dan kendala yang dihadapi. Dimana jika membutuhkan suatu laporan barang atau data harus mengecek kembali dipembukuan yang ada pada instansi sehingga membutuhkan banyak waktu dan tenaga. Untuk itu, dibutuhkan suatu sistem yang mampu membantu tugas pegawai yang bisa memberikan dampak yang signifikan untuk mengubah pekerjaan sebelumnya lamban menjadi lebih cepat.

Pada saat ini perkembangan teknologi informasi sangat cepat secara global dan tanpa adanya batasan waktu. Pekerjaan manusia yang dahulu dikerjakakan secara manual, dengan adanya teknologi komputer sehingga segala proses manual menjadi serba komputerisasi. Dalam inventory Toko Latar Outdoor tidak lepas dari proses pembuatan laporan yang terkait dengan proses yang dijalankan dalam inventory ini. Laporan yang dihasilkan dalam koperasi ini meliputi laporan dalam hal penjualan dan pengadaan yang meliputi laporan data supplier, laporan stok barang, laporan transaksi barang masuk, laporan transaksi barang keluar, pengembalian barang afkir, dan laporan penjualan.

Berdasarkan permasalahan tersebut, maka dibutuhkan sebuah perancangan untuk sistem inventory pada Toko Latar Outdoor. Seperti yang diketahui secara umum perancangan merupakan proses pengembangan spesifikasi baru berdasarkan rekomendasi hasil analisis sistem (Subhan, 2012). Sedangkan perancangan dalam pembangunan sebuah sistem informasi merupakan sebuah proses yang 
menggambarkan alur kerja sistem informasi dalam bentuk diagram antara lain Data Flow Diagram (DFD), Flowchart dan Mockup (Rhomadhona, 2018). Sedangkan untuk persediaan barang dan jasa merupakan barang- barang yang disimpan untuk digunakan atau dijual pada masa yang akan datang (Ristono,2009). Selain itu, menurut Ikatan Akuntan Indonesia (Gumelar, 2019) Persediaan adalah aset tersedia untuk dijual dalam kegiatan usaha normal, dalam proses produksi dan dalam perjalanan serta dalam bentuk bahan atau perlengkapan (supplies) untuk digunakan dalam proses produksi atau pemberian jasa. Menurut Sartono (2009) Persediaan merupakan suatu aktiva yang meliputi barang - barang milik perusahaan dalam maksud untuk dijual dalam suatu periode usaha tertentu atau persediaan barang barang yang masih dalam pengerjaan atau proses produksi ataupun persediaan bahan baku yang menunggu penggunaannya dalam proses produksi.

Penelitian ini akan mambahas mengenai pembangunan sistem inventory pada Toko Latar Outdoor ini menggunakan bahasa pemrograman Java Netbeans dan Mysql. Adapun penelitian tersebut bertujuan untuk memberikan solusi yang terbaik kepada pimpinan toko pada khususnya. Seperti penelitian yang telah dilakukan oleh Yuhendra (2014) dengan membangun sebuah sistem invntory sparepart mobil pada CV Autoparts Toyota menggunakan bahasa pemrograman Java. Selaras dengan Junaidi dkk (2015) yang juga membangun sebuah sistem inventory pada sebuah perusahaan berbasis desktop menggunakan JSE dan MySQL yang dapat memonitoring arus barang masuk dan barang keluar sehingga menghasilkan pelaporan yang cepat dan akurat. Selain itu, Hasanah dkk (2020) juga membangun sistem yang sama hanya saja peneliti tersebut fokus untuk memonitoring aktivitas mekanik di sebuah PT.UT cabang Satui dengan mengumpulkan beberapa formulir ke supervisor, dimana aplikasi tersebut dibangun menggunakan bahasa pemrograman PHP dan MySQL. Kebanyakan peneliti membangun sebuah sistem informasi menggunakan bahasa pemrograman PHP untuk itu dalam penelitian ini membangun sebuah sistem inventory menggunakan bahasa pemrograman Java Netbeans. Dimana menurut Rosidah (2018) Netbeans merupakan salah satu IDE (Integrated Development Environment) open source yang dikembangkan dengan bahasa pemrograman java. Netbeans mempunyai lingkupan pemrograman yang terintegraasi dalam suatu perangkat lunak yang didalamnya menyediakan pembangunan pemrograman GUI, text editor, compiler, interpreter dan suatu debugger

\section{METODE PENELITIAN}

Metode penelitian yang peneliti lakukan adalah metode penelitian dengan tahapan sebagai berikut:

1. Model Pengembangan Sistem

Model pengembangan sistem merupakan langkah dan prosedur yang akan dilakukan dalam pengumpulan data atau memecahkan permasalahan sehingga akan didapat suatu kebenaran atas data yang diperoleh. Dalam penelitian ini, peneliti menggunakan metode Waterfall.

2. Metode Pengumpulan Data

Metode pengumpulan data yang dilakukan oleh peneliti untuk mendapatkan data-data serta informasi untuk mendukung penyempurnaan hasil dari penelitian ini antara lain :

a. Obeservasi

Kegiatan ini memerlukan alat pencatat data yang spesifik, dimana hasil observasi ini akan dianalisis kemudian dicatat ke dalam fungsi-fungsi yang telah ditentukan untuk mencapai data yang valid. Observasi dilakukan pada tanggal 27 April 2020 di Toko Latar Outdoor, dengan mengamati proses sistem pengolahan data inventory barang. Peneliti melakukan observasi untuk melihat secara langsung sistem berjalan di Toko Latar Outdoor. Kegiatan ini dilakukan untuk mendapatkan gambaran secara objektif sehingga dapat mengetahui apa saja yang diperlukan untuk membuat rancangan sistem aplikasi inventory.

b. Wawancara

Wawancara yang digunakan dalam penelitian ini yaitu wawancara terstruktur atau terbuka yang tidak menggunakan pedoman wawancara yang telah tersusun secara sistematis. Dengan konidsi saat ini metode wawancara dilakukan secara zoom meet terhadap owner/pemilik toko yaitu saudara Yogi Rizkyansyah, S.E. Wawancara dengan tujuanuntuk mencari informasi mengenai proses penyelenggaraan sistem inventory toko latar outdoor. Dalam wawancara kepada pemilik toko terdapat beberapa pertanyaan yaitu:

1. Sudah berapa lama berdirinya Toko Latar Outdoor? 
2. Apa alasan anda membuka bisnis dibidang tersebut?

3. Ada berapakah item atau jenis barang pada Toko ini?

4. Apa tantangan utama dalam menjalankan usaha seperti ini?

5. Bagaimana cara anda untuk mengembangkan usaha ini setelah adanya marketplace?

6. Bagaimana cara untuk mempertahankan setelah berjalannya usaha ini?

7. Bagaimana cara anda mengelolah pada bisnis ini?

8. Startegi apa yang digunakan untuk memanage siklus perputaran barang yang keluar atau masuk pada Toko ini?

c. Studi pustaka

Pengumpulan informasi dibutuhkan dalam mencari referensi-referensi yang berhubungan dengan penelitian yang dilakukan. Pengumpulan informasi yang penulis lakukan dalam penelitian ini yaitu dengan cara:

a. Mempelajari buku-buku literatur mengenai analisis dan desain suatu sistem.

b. Mempelajari sistem inventory toko outdoor yang akan dibuat.

c. Mempelajari buku-buku bahasa pemrograman PHP dan basis data MySQL untuk merancang dan membuat sistem inventory toko outdoor berbasis Desktop.

3. Langkah-Langkah Pengembangan Sistem

Siklus hidup pengembangan sistem dapat dibagi dalam tahapan sebagai berikut :

\section{Requirements analysis and definition}

Pada tahap requirements analysis and definition, penulis melakukan studi pustaka mengenai sistem inventory toko latar outdoor, pengembangan perangkat lunak, kajian penelitian yang relevan untuk mendapatkan metode pengembangan yang dapat dijadikan referensi dalam penelitian, dan studi lapangan untuk mendapatkan data dan kebutuhan spesifikasi sistem inventory toko latar outdoor yang dapat diakses secara lokal. Kebutuhan yang diperlukan di Toko Latar Outdoor yaitu sistem inventory barang toko outdoor yang efektif dan efisien. Untuk memenuhi kebutuhan tersebut, diperlukan sistem inventory toko latar outdoor berbasis komputer yang memiliki keunggulan proses pengolahan data tidak menggunakan kertas, proses evaluasi cepat, dan mudahnya pengarsipan data laporan.

2. System and Software Design

Perancangan meliputi desain diagram, desain tampilan, dan desain database sebagai berikut:

a. Desain Diagram

Diagram sistem inventory toko latar outdoor ini memiliki 5 entitas, yaitu owner, admin, petugas gudang, supplier, dan outlet yang berfungsi sebagai user atau pengguna sistem. Tugas owner yaitu sebagai penerima laporan dari data barang, barang masuk, barang keluar, barang afkir, pengembalian barang afkir, data supplier. Admin bertugas Melakukan pencatatan semua transaksi barang masuk dan barang keluar, barang afkir, pengembalian barang afkir dan melakukan laporan stok data barang kepada kepala toko.

b. Desain Interface

Sistem perancangan tampilan inventory toko latar outdoor ini terbagi menjadi 2 tingkatan kategori user. Tingkatan kategori user diklasifikasikan berdasarkan fungsi dari pengguna sistem, di antaranya user ownerr dan user admin.

c. Desain Database

Proses pembuatan data pada sistem dapat dipermudah dengan menggunakan database sebagai media penyusun data. Operasi database yang dapat dilakukan pada sistem inventory toko latar outdoor ini yaitu menambah data user, menghapus data user, membuat transaksi barang masuk, barang keluar, data barang, barang afkir, pengembalian barang afkir, menghapus data transaksi barang masuk, barang keluar, data barang, barang afkir, pengembalian barang afkir, menyimpan data transaksi barang masuk, barang keluar, data barang, barang afkir, pengembalian barang afkir, mengedit data transaksi barang masuk, barang keluar, data barang, barang afkir, pengembalian barang afkir, membatalkan data transaksi barang masuk, barang keluar, data barang, barang afkir, pengembalian barang afkir.

\section{Implementation and Unit Testing}

Dalam penelitian ini digunakan bahasa pemrograman Java Netbeans dan MySQL sebagai basis 
data-nya sehingga implementasi dapat berjalan cepat dan mudah.

\section{Integration and System Testing}

Tahap integration and system testing dilakukan dengan pengujian black box testing untuk memastikan keseluruhan fungsi dari sistem yang telah dikembangkan. Pengujian black box testing adalah pengujian aspek fundamental sistem tanpa memerhatikan struktur logika internal perangkat lunak. Metode ini digunakan untuk mengetahui apakah perangkat lunak sudah berfungsi dengan benar. Pengujian black box testing merupakan metode perancangan data uji yang mendasarkan pada spesifikasi perangkat lunak.

\section{Operation and Maintenance}

Pada tahap operation and maintenance dilakukan pengoperasian di Tokp Latar Outdoor dengan pengguna secara terbatas, dan pengoreksian kesalahan pada sistem yang baru diketahui pada saat sistem sedang digunakan. Dengan ini, pemeliharaan terhadap sistem dapat diketahui kesalahannya agar dapat segera diperbaiki dan diketahui apakah sistem yang dibuat sudah layak digunakan.

\section{HASIL DAN PEMBAHASAN}

\section{Aturan Bisnis Sistem Inventory pada Toko Outdoor}

Dalam aturan bisnis didalamnya menjelaskan tentang kebijakan-kebijakan pada sistem yang dibahas antara lain:

a. Pendataan Supplier

Setiap kedatangan supplier, supplier memberikan data-data didalamnya berisikan seperti id supllier, nama supplier, no telepon, dan alamat. Admin mendata setiap kedatangan supplier dan admin menerima data supplier.

b. Pendataan Petugas

Setiap datangnya barang masuk yang dari supplier, petugas mengecek terlebih dahulu dengan kondisi barang, dan jumlah barang yang dikirim oleh supplier, setelah petugas mengecek barang menginfokan ke bagian admin barang sudah dicek oleh petugas, dan admin rekap tanda terima barang afkir yang telah diperiksa oleh petugas, admin mendata barang-barang afkir, dan petugas menerima tanda terima barang afkir yang telah dibuat oleh admin, lalu admin membuat laporan barang afkir yang akan diberikan kepada kepala toko.

b. Pendataan Data Stok Barang

Admin melakukan pengecekan persediaan barang yang ada di stok data barang, dan mendata daftar barang yang ada di data stok barang, admin menerima daftar-daftar barang yang ada di data stok barang dan membuat laporan data stok barang yang akan diberikan kepada kepala toko.

c. Pendataan Barang Masuk

Supplier melakukan pengirimin barang, admin mendata barang dan menerima daftar barang yang masuk dari setiap supplier saat pengirim barang ke Toko Latar Outdoor, kemudian admin mencatat barang masuk yang dari supplier untuk disimpan pada buku data stok barang, supplier menerima tanda terima barang yang telah dibuat oleh admin, dan membuat laporan data stok barang yang akan diberikan kepada kepala toko.

d. Pendataan Barang afkir

Admin mendata semua data barang yang retur dari supplier yang telah dicek oleh petugas gudang, kemudian admin membuat database barang afkir. Setelah itu data-data barang afkir yang telah dibuat kemudian di simpan di database barang afkir, admin membuat tanda terima barang afkir untuk petugas dan admin membuat laporan barang afkir untuk diberikan kepada kepala toko.

e. Pendataan Pengembalian Barang afkir

Admin mendata semua barang yang telah retur untuk di kembalikan ke supplier, kemudian diproses pada databse pengembalian barang afkir. Setelah itu data pengembalian barang afkir yang telah dibuat oleh admin kemudian di simpan di databse pengembalian barang afkir, admin merekap pengembalian barang afkir untuk supplier, lalu supplier menerima faktur pengembalian barang afkir dari admin, setelah itu admin membuat laporan pengembalian barang afkir untuk kepala toko.

f. Pendataan Barang Keluar

Sales toko melakukan permintaan barang ke Toko Latar Outdoor, admin menerima permintaan barang dari sales toko, dan admin membuat rekap nota barang keluar untuk diberikan kepada sales 
toko, sales toko menerima barang dan nota barang keluar, kemudian admin membuat laporan baang keluar yang akan diberikan kepada kepala toko.

g. Proses Laporan Data Stok Barang

Laporan data stok barang di simpan dalam databse stok barang kemudian di serahkan kepada kepala toko. Kepala toko akan menerima laporan stok data barang berupa dengan dokumen.

h. Proses Laporan Barang Masuk

Laporan data barang masuk di simpan dalam databse barang masuk kemudian di serahkan kepada kepala toko. Kepala toko akan menerima laporan barang masuk berupa dengan dokumen.

i. Proses Laporan Barang afkir

Laporan data barang afkir di simpan dalam databse barang afkir kemudian di serahkan kepada kepala toko. Kepala toko akan menerima laporan barang afkir berupa dengan dokumen.

j. $\quad$ Proses Laporan Pengembalian Barang afkir

Laporan pengembalian barang afkir di simpan dalam databse pengembalian barang afkir kemudian di serahkan kepada kepala toko. Kepala toko akan menerima laporan barang afkir berupa dengan dokumen.

k. Proses Laporan Barang Keluar

Laporan data barang keluar di simpan dalam databse barang keluar kemudian di serahkan kepada kepala toko. Kepala toko akan menerima laporan barang keluar berupa dengan dokumen.

\section{Diagram ERD (Entity Relationship Diagram)}

Terdapat 7 (tujuh) entitas pada Sistem Inventory Toko Outdoor yaitu supplier, data barang afkir, pengembalian barang afkir, petugas, data barang, barang masuk dan barang keluar. Seperti yang ditunjukkan pada gambar 1 berikut.

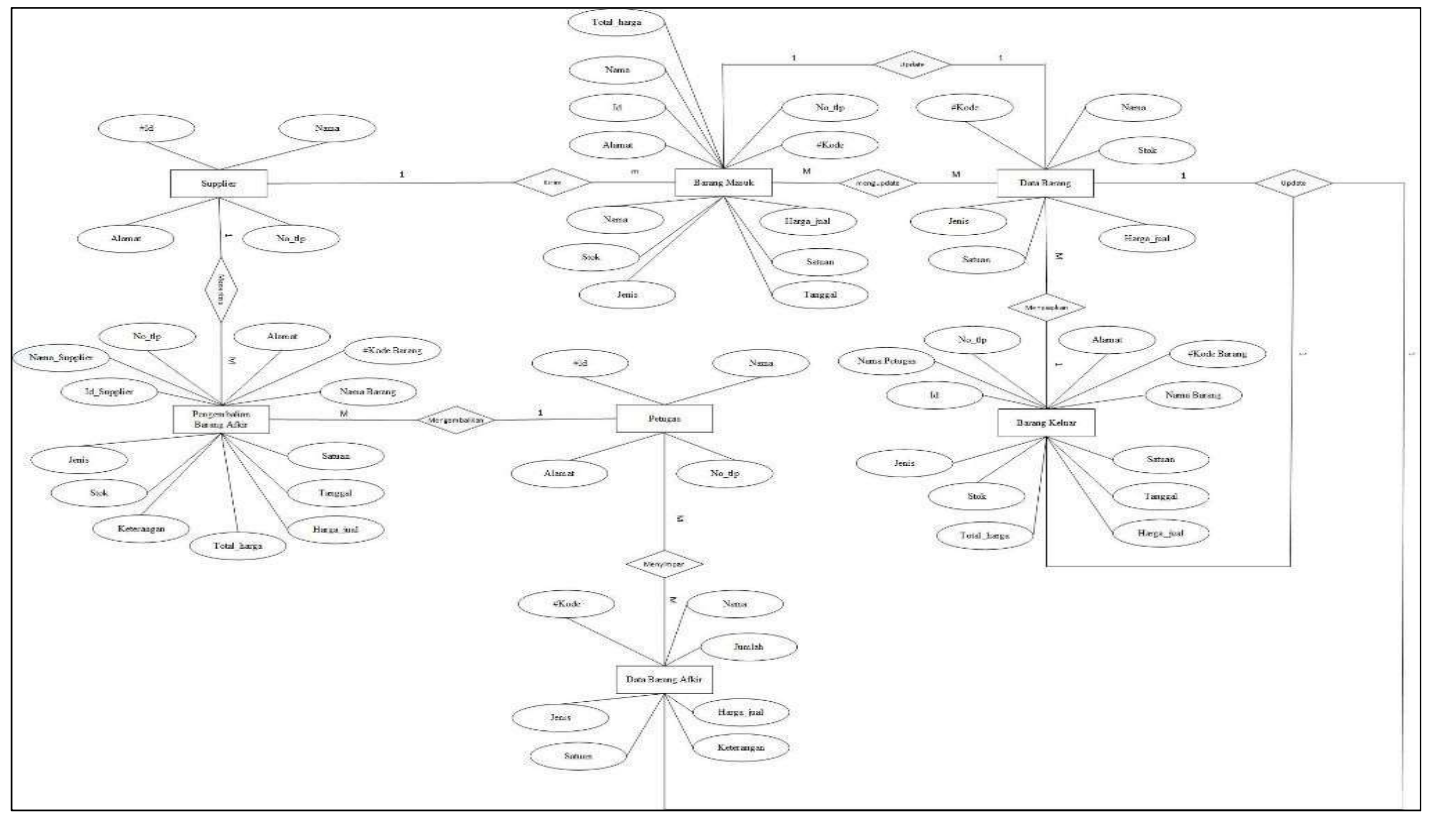

Gambar 1. Diagram ERD (Entity Relationship Diagram)

\section{Data Flow Diagram (DFD)}

Dalam penelitian ini percangan untuk alur kerja sistem inventory digambarkan menggunakan Data Flow Diagram (DFD). Gambar 2 merupakan diagram konteks dari keseluruhan sistem inventory, yang mana diagram konteks merupakan bagian utama dari Data Flow Diagram (DFD). 


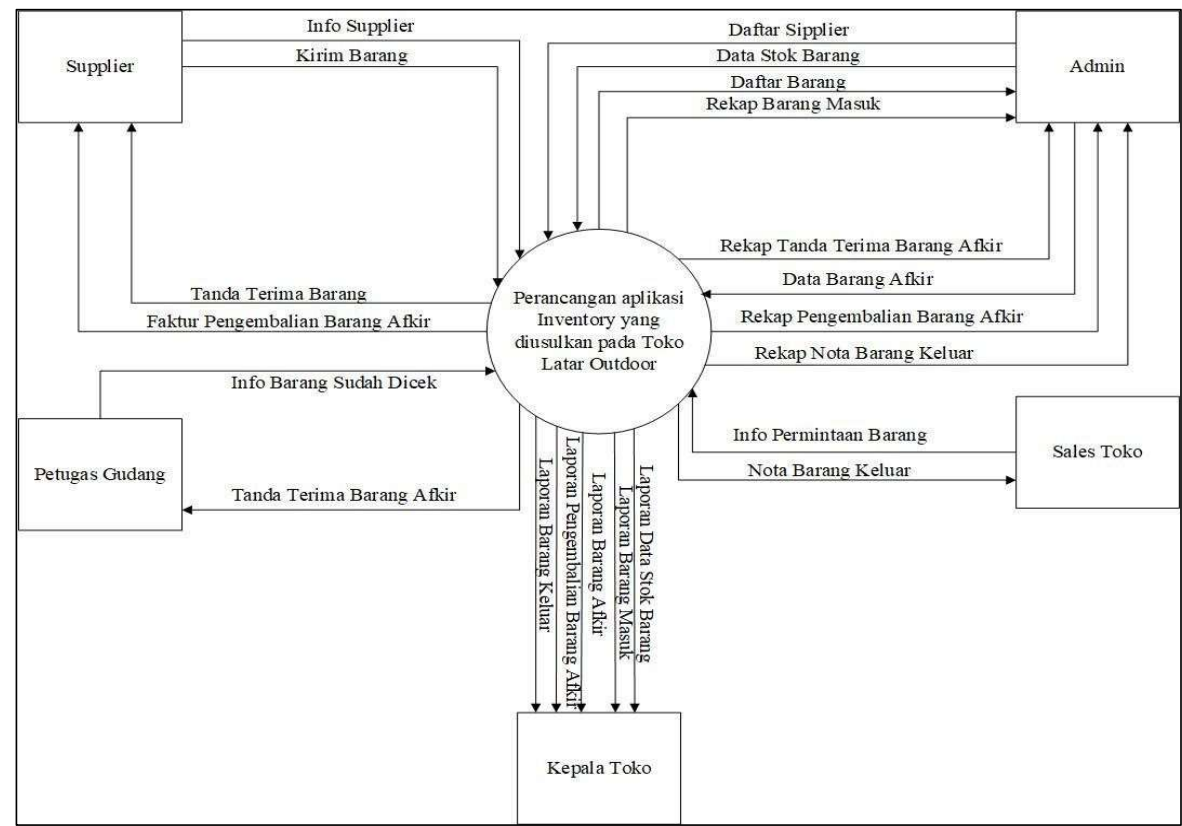

Gambar 1. Diagram Konteks yang diUsulkan

4. Tampilan sistem inventory toko outdoor

4.1 Tampilan halaman utama

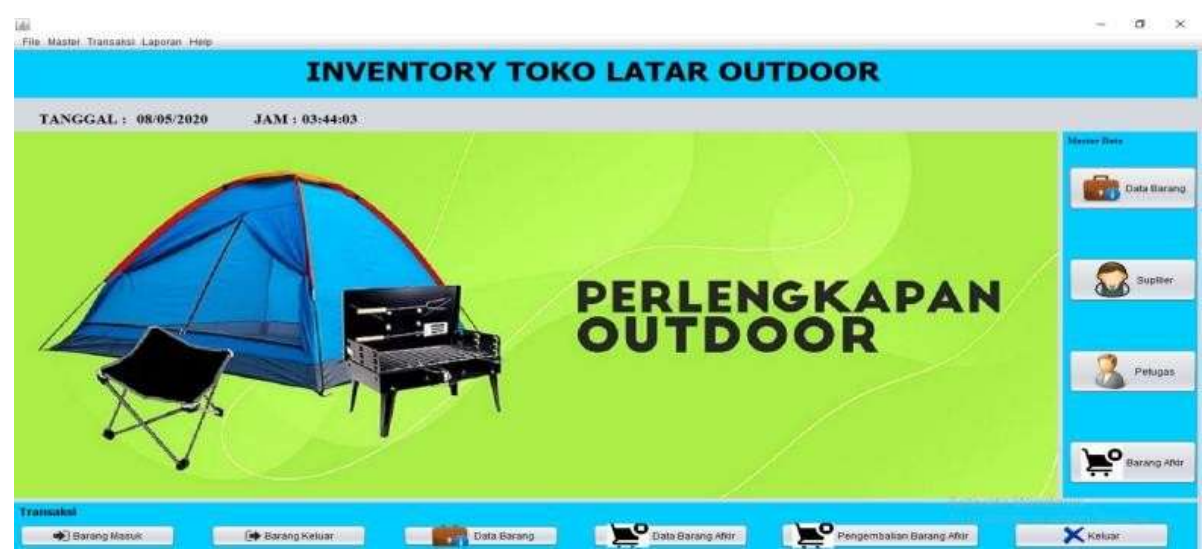

Gambar 3. Tampilan Halaman Utama

Tampilan ini adalah merupakan tampilan utama pada aplikasi Inventory. Dalam tampilan ini terdapat menu-menu yang berfungsi untuk mengakses form yang ada pada aplikasi Inventory.

\subsection{Tampilan Data Barang}

Gambar 4 merupakan tampilan form data barang baru yang berfungsi untuk mendata data barang pada saat diterima dari supplier. Pada form ini Admin dapat menyimpan, mengubah, membatalkan dan menghapus dari database. 


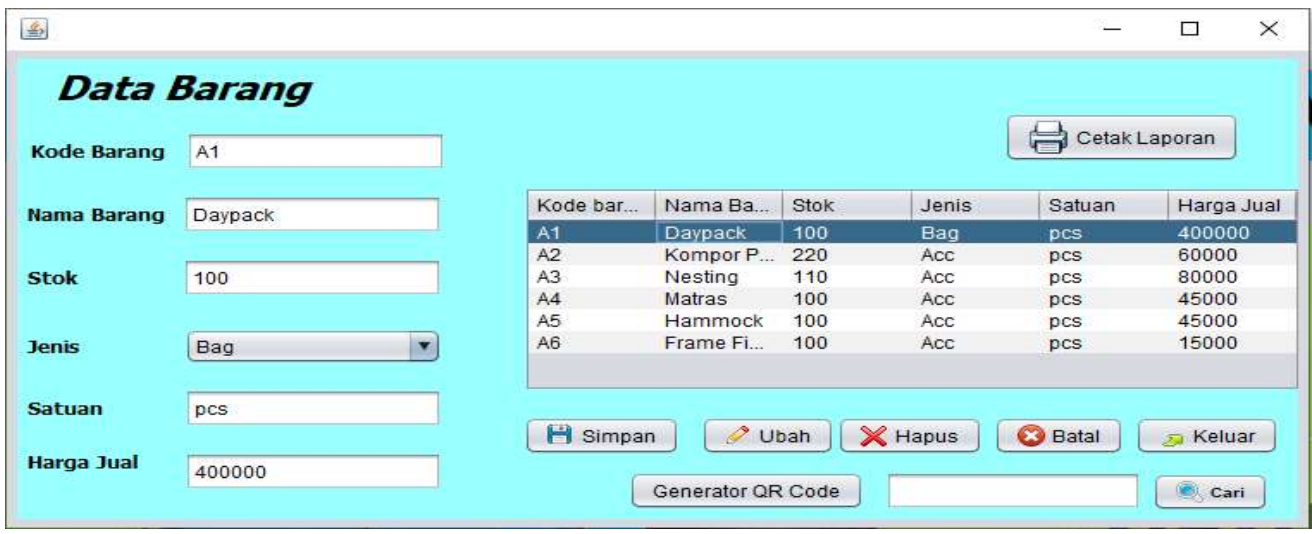

Gambar 4. Tampilan Layar Form Data Barang

4.3 Tampilan Data Petugas

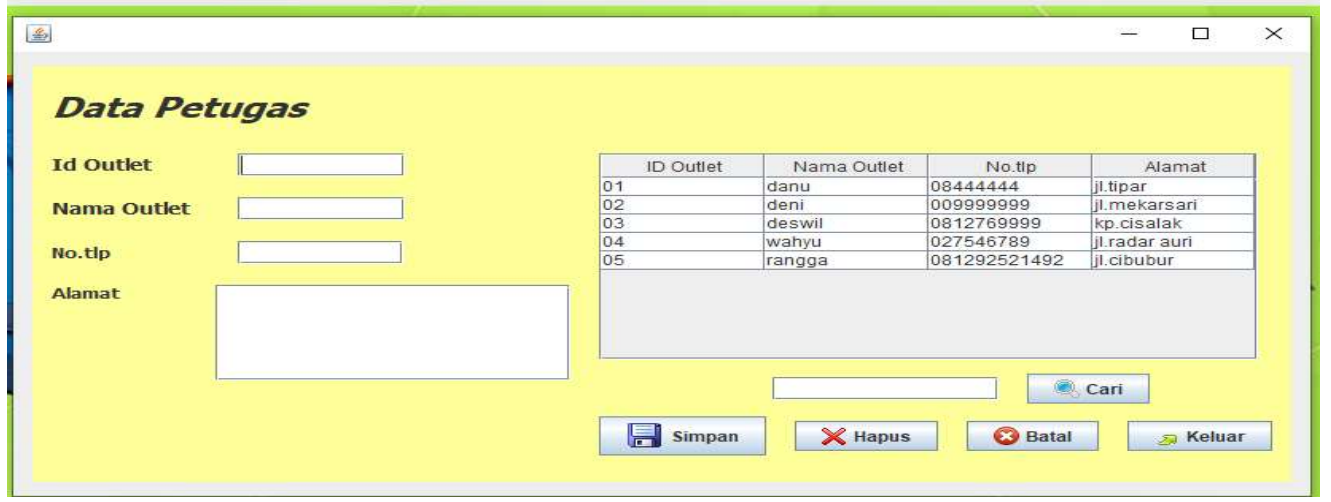

Gambar 5. Tampilan Layar Form Data Petugas

Tampilan ini merupakan tampilan form data petugas yang berfungsi untuk memasukan data petugas. Pada form ini Admin dapat menyimpan, mengubah, membatalkan dan menghapus data petugas.

\subsection{Tampilan Data Supplier}

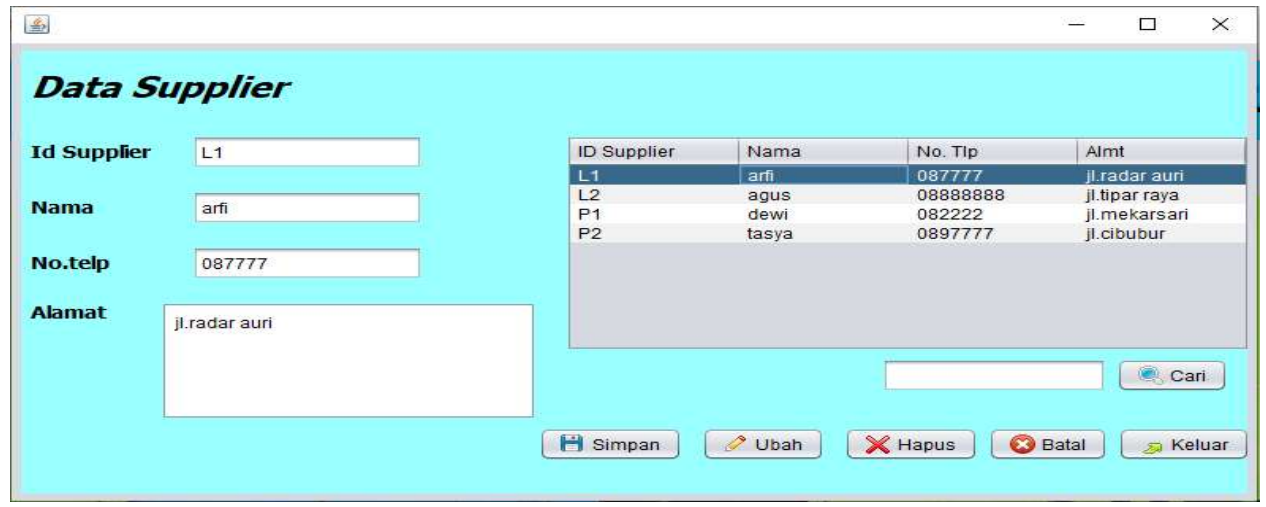

Gambar 6. Tampilan Layar Data Supplier

Tampilan ini merupakan tampilan form data supplier yang berfungsi untuk memasukan data supplier. Pada form ini Admin dapat menyimpan, mengubah, membatalkan dan menghapus data supplier.

4.5 Tampilan Data Barang Masuk dan Keluar 


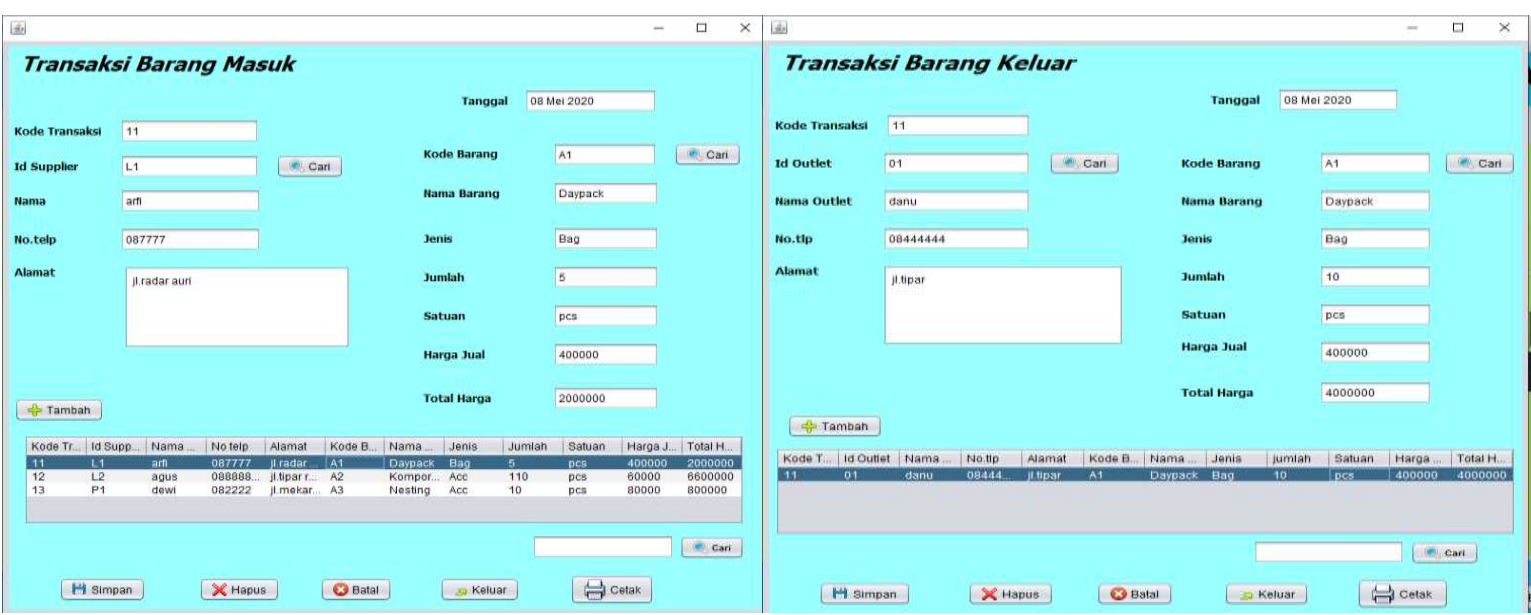

Gambar 7. Tampilan Layar Transaksi Barang Masuk dan Keluar

Tampilan ini merupakan tampilan form transaksi barang masuk dan barang keluar yang berfungsi untuk memasukan data barang masuk. Pada form ini Admin dapat menyimpan, mengubah, membatalkan dan menghapus data supplier.

\subsection{Tampilan Data Barang Afkir dan Pengembalian Barang Afkir}

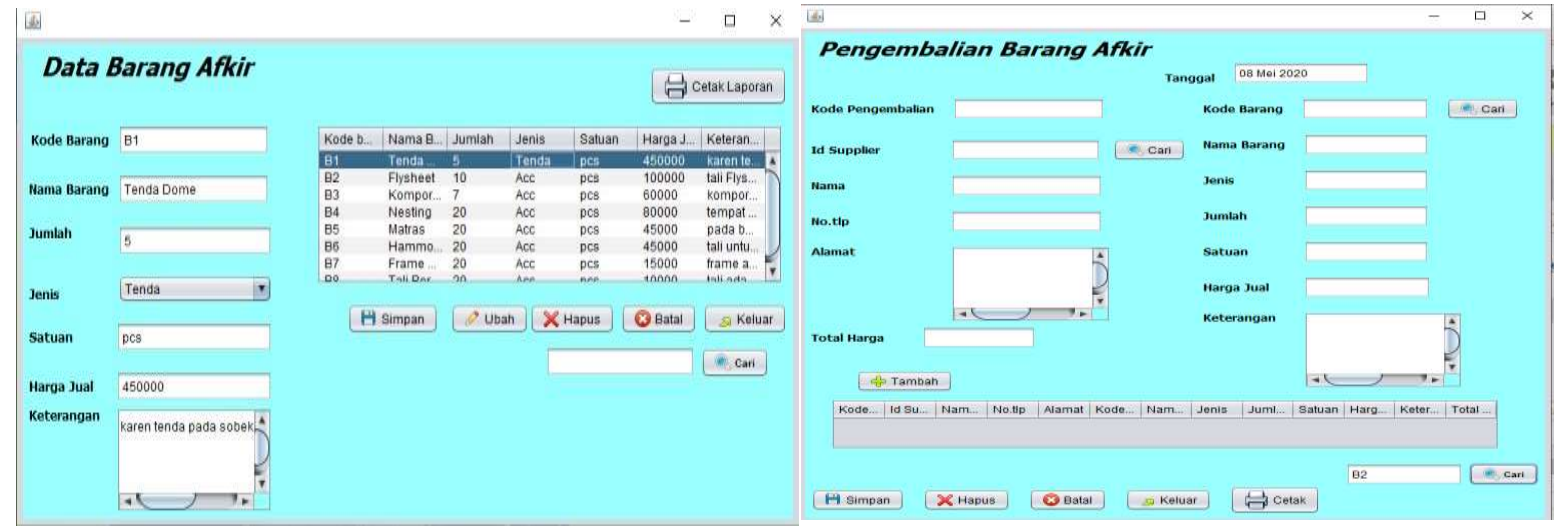

Gambar 8. Tampilan Layar Data Barang Afkir dan Pengembalian barang afkir

Tampilan ini merupakan tampilan form barang afkir dan form pengembalian barang afkir yang berfungsi untuk memasukan data barang afkir. Pada form ini Admin dapat menyimpan, mengubah, membatalkan dan menghapus data barang afkir.

4.7 Tampilan Laporan data barang masuk dan transaksi barang masuk

Tampilan ini merupakan tampilan layar laporan data barang yang berfungsi untuk menampilkan data barang yang telah masuk di dalam sistem inventory dan tampilan laporan transaksi barang masuk yang berfungsi untuk menampilkan transaksi barang masuk yang telah masuk di dalam sistem inventory. Pada form ini Admin akan menampilkan laporan data barang yang tersimpan di sistem inventory. 

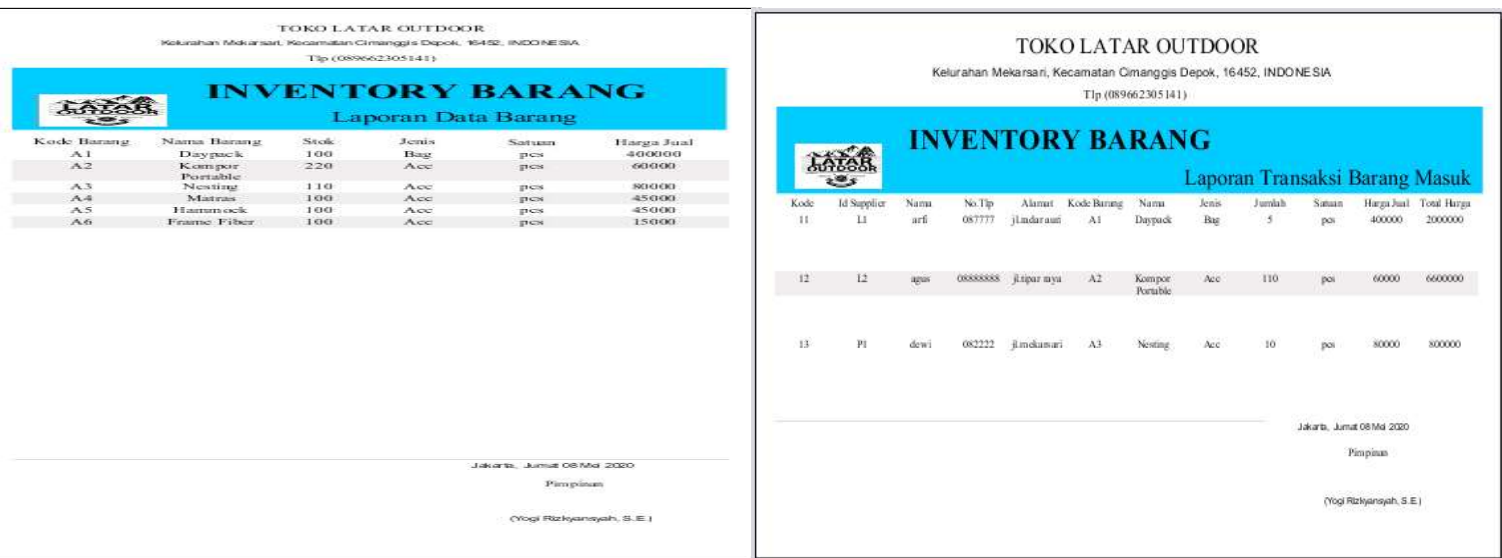

Gambar 9. Tampilan Layar Laporan Data Stok Barang dan Laporan Transaksi Barang Masuk

4.8 Tampilan Laporan data barang afkir dan pengembalian barang afkir

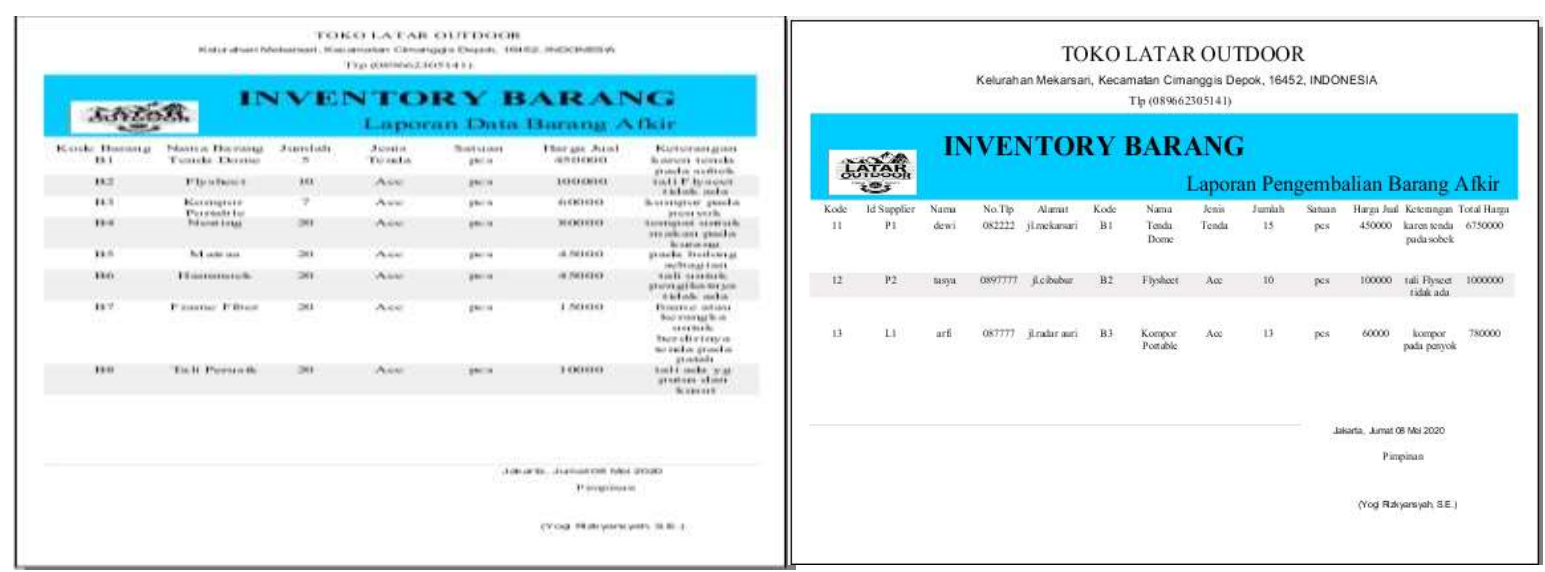

Gambar 10. Tampilan Layar Laporan Data Barang afkir dan pengembalian barang afkir

Tampilan ini merupakan tampilan layar laporan data barang afkir yang berfungsi untuk menampilkan data barang afkir yang telah masuk di dalam sistem inventory. Sedangkan laporan pengembalian barang afkir yang berfungsi untuk menampilkan data pengembalian barang afkir yang telah masuk di dalam sistem inventory. Pada form tersebut Admin akan menampilkan laporan data barang afkir yang tersimpan di sistem inventory.

\section{SIMPULAN}

Berdasarkan analisa yang telah di uraikan dari bab sebelumnya, maka dapat disimpulkan perihal Perancangan Sistem Aplikasi Inventory Toko Outdoor Berbasis Java Pada Latar Outdoor sebagai berikut:

1. Setelah adanya sistem berjalan yang mampu mengelola data penjualan dan pembelian sehingga dapat mengefektifkan dan mengefisienkan kinerja proses transaksi pada inventory.

2. Proses pemesanan pembelian barang dari supplier menjadi lebih mudah karena dalam proses pengecekan stok barang di inventory menjadi lebih mudah.

3. Proses rekap data, laporan-laporan penjualan dan pembelian barang menjadi lebih efektif dan sefisien karena sudah tersimpan di dalam database yang ke mungkinan kecil terjadinya kehilangan atau kerusakan dokumen.

\section{DAFTAR PUSTAKA}

Gumelar, A. (2019). Pengertian Persediaan Menurut Para Ahli. Persediaan Menurut Para Ahli.

Hasanah, N., Rhomadhona, H., \& Noor, M. (2020). Aplikasi Backlog Pada PT United Tractors, Tbk Site- 
工4

Jurnal Humaniora Teknologi

p-ISSN: 2443-1842

Volume 6, Nomor 2, Oktober 2020

Satui. Jurnal Sains dan Informatika, 6(1), 20-27.

Junaidi, J., Arifin, R., \& Septiani, A. (2015). Rancang Bangun Aplikasi Sistem Inventory Berbasis Desktop Menggunakan JSE. Proceedings Konferensi Nasional Sistem dan Informatika (KNS\&I).

Rhomadhona, H. (2018). Penerapan Teknologi QR Code Berbasis Web untuk Absensi Pegawai pada BKPSDM Kabupaten Tanah Laut. Jurnal Humaniora Teknologi, 4(1).

Rosidah;. (2018). Bab Ii Landasan Teori. Journal of Chemical Information and Modeling, 53(9), 8-24. https://doi.org/10.1017/CBO9781107415324.004

Subhan, M. (2012). Analisa Perancangan Sistem. Jakarta: Lentera Ilmu Cendekia.

Yuhendra, Y. (2014). Perancangan Sistem Inventory Spare Parts Mobil Pada Cv. Auto Parts Toyota Berbasis Aplikasi Java. Jurnal Teknoif, 1(2). 